\title{
THE PROFUNDITY OF HADITH MATERIALS ON 'ISLAM ITU INDAH" ON TRANS TV
}

\author{
Nurun Najwah \\ State Islamic University (UIN) Sunan Kalijaga Yogyakarta \\ najwahnurun@gmail.com
}

\begin{abstract}
In Indonesia, "Islam Itu Indah (Islam is beautiful)" religious program on Trans TV is a "preaching-tainment" which has a high rating. On the one hand, viewers give a positive response because they consider the materials of the $d a^{\prime} w a h$ delivered are actual, easy to understand, and entertaining. On the other hand, a negative response emerged from Muslim scholars and intellectuals, seeing as a change in religious authority that should be based on the mastery of Islamic sciences (Muslim scholars) shifted to media authorities ( $d a^{\prime} i$-celebrities), in which the material aspect is less qualified, and the delivery methods are inappropriate. This research specifically discussed the profundity of hadith materials on the program to see the characteristics of the delivery of hadith as a source of reference of $d a^{\prime} i$ in explaining certain material, and how the tendency in interpreting the hadith. The research method used was qualitative research with qualitative descriptive analysis approach, with observation and documentation. The observation on six episodes in 2017 showed that the $d a^{\prime} i$ were generally less profound in explaining the hadith, e.g., not fully explaining the text of hadith (sanad and matan), the source of the hadith book and its quality, and understanding the hadith textually with a cursory explanation. As a recommendation, it is necessary to involve the Islamic scholars in the preparation materials of $d a^{\prime} w a h$ and the need visualization of hadith text, translations, referral sources, and the quality of the hadith.
\end{abstract}

Keywords: preaching on television, hadith materials, hadith in media, Islam itu indah

\section{Introduction}

Islam Itu Indah religious program on Trans TV began showing on December 12, 2010. The program showing every morning for ninety minutes $(05.00-06.30 \mathrm{a} . \mathrm{m}$.) is the result of a taping attended by the women assemblies from various regions in Indonesia with the main $d a^{\prime} i$ Muhammad Nur Maulana popular with the jargon Jama'ah, Oh Jama'ah, Alhamdu-lillah and his partners Oki Setiana Dewi and Syamsuddin Nur as well as some guest preacher is called usthad (teacher) invited alternately, such as Kahfi, Lulu Susanti, Cecep Maulana, and others. However, Maulana icon still holds a key role in the program, with a turban always hung around the neck and sometimes used as a property, the usthad's unique and high-appeal personality, funny style of speaking and humorous makes the program gets a high rating and still exists until now, and enters 5 most popular morning nominees of ITA (Indonesian Television Awards) version 2016. (www.celebrity.okezone.com, accessed 2017, February 22).

Some studies conclude that there is a positive response regarding rhetoric and preaching strategy in Islam Itu Indah. The delivery of da'wah materials with actual themes and the language easy to understand, interspersed with humor, NASH group's songs, illustrations, inspirational stories, and dialogue between speakers and the guests (celebrities) have an entertainment side that is so interesting to see (Hawa, 2016; Arifin, 201; Maulana, 2015; Ummin, 2015).

However, negative response also arises related to the materials and style of da'wah (with joking). Regional Heads of Muhammadiyah (Pimpinan Wilayah 
Muhammadiyah) and Regional Heads of Nahdlatul Ulama (Pimpinan Wilayah Nahdlatul Ulama) of Special Region of Yogyakarta gave negative perception of Islam Itu Indah religious program, especially regarding the materials and the performers (Setyaningsih, 2012). Similarly, Habib who specifically highlights the $d a^{\prime}$ wah materials of seven episodes finds many explanations which do not include the postulates from Al-Qur'an, hadith, and the opinions of the scholars, and some of the postulates used were incorrect (Habib, 2014). A lot of sharp criticism was also conveyed by Ali Mustafa Yaqub (the deceased), Syuhada Bahri as a Chairman of the Indonesian Council on Islamic Mission (Dewan Dakwah Islam Indonesia), and Ma'ruf Amin as a Chairman of the Indonesian Council of Ulema (Majelis Ulama Indonesia), related to the shallowness of the materials, and the speakers' knowledge and delivery that is inappropriate.This article specifically discussed the profundity of hadith, cause, in the hadith study, the validity of hadith texts and how to interpret them are the main focus must be observed (Ajjaj, 1989). This is very important because the source of the text of the hadith used as the reference must be the text of the hadith believed to be the hadith of the Prophet (hadith which is qualified shahih and hasan), not just any hadith that is dha'if (weak) or maudhu' (false). The complexity of hadith materials, the more varied redaction of the hadith (bil lafdzi and bil $\left.m a^{\prime} n a\right)$, the various qualities of the hadith (shahih, hasan, dha'if, and maudhu'), the various Books of the hadith (the Book of Primary Hadith, Hadith of non-Hadith Book with various systematics), making selectivity in filtering the text of hadith to be used as a reference is a must. The research on its program on Trans TV by looking at the characteristics of the delivery of hadith as a referral source of the $d a^{\prime} i$, as well as how the tendency to interpret the hadith. The method used in this research was a qualitative research with qualitative descriptive analysis approach, observation and documentation as the data collection techniques of those programs.

\section{Study of Hadith on "Islam Itu Indah"}

As the second source of Islamic teachings, hadith/sunna of the Prophet has always been referred to by $d a^{\prime} i$ (preacher) to explain his preachings Therefore, the research was focused on how the da'i quote or explain the hadith (original text or translation, the completeness of sanad and matan, the quality of the hadith, the referral source of Book, oral or visual appearance) and how the tendency to interpret the hadith (textually or contextually) on six episodes in January to March 2017 randomly.

The six episodes studied were as follow:

1. Liburan Yuuuk (Let's go on vacation!), showed on 2017, January 07, with the speakers: Maulana, Cecep, Oki, and Syam

2. Hidup Setelah Mati (Live after Death), showed on 2017 February 15, with the speakers: Maulana, Kahfi, and Oki

3. Jangan Pilih Kasih (Don't Play any Favor), showed on 2017, February 16, with the speakers: Syam, Maulana, and Kasim

4. Mana Janjimu (Where's Your Promise?), showed on 2017, February 17, with the speakers: Maulana, Cecep, and Oki

5. Jurus Ampuh Cari Jodoh (The Effective Ways to Find a Soul Mate), showed on 2017, March 16, with the speakers: Maulana, Syam, Kahfi, and Lulu

6. Sang Penjilat (The Sycophant), showed on 2017, March 18, with the speakers: Maulana, Syam, Lulu, and Luthfia

Based on the observation of the six episodes, the ways the da'i quoted the Prophet's hadith can be classified into three categories:

First, by mentioning part of matan of hadith orally:

a. Innamal A 'mal bin Niyaat (Oki and Syam) 
b. Da'wah al-madhluum wa da'wah al-musaafir wad a'wah al-waalid 'alaa waladihi (Oki)

c. Alhamdulillahi Ahyaana ba'dama amaatana wa ilaihin nusyur (Maulana)

d. Sab'ah yudhillahum Allaah yauma al-Qiyaamah fii dhillihi Yauma laa dhilla illaa dhillahu, Imaam 'aadil (Kasim)

e. walad shalih yad'u lahu (Kasim)

f. Aayatul munaafiq tsalaats idzaa hadatsa kadzaba wa idza wa'ada akhlafa wa idza tumina khaana (Cecep)

g. Tunkahu al-mar 'ah li-arba` limaalihaa wa lihasabihaa wa jamaalihaa wa lidiinihaa fadhfar bidhaati ad-diin taribat yadaaka (Lulu)

h. Man ahabba an-yubsatha lahu fii rizqihi wa yunsa'a lahu fii atsarihi falyashil rahimahu (Lulu)

i. Ridhallah fi Ridhalwalidaini wa sukhtullah fi sukhtil walidaini (Lulu)

j. an-Nikaahu mun sunnatii faman lam yastathi ' bisunnatii falaisa minnii (Lulu)

k. hubbu ad-dunya wa karahiya al-maut (Lulu)

1. la tadkhulu al-Jannata qath u rahimi (Lulu)

m. Tahaaduu Tahaabuu (Syam)

n. hadza min fadzli Rabbi (Lulu)

o. Qul khairan au liyashmut (Lulu)

Second, by mentioning some sanad/sources of the Book, and explaining the outline of the hadith content:

a. From Abu Hurairah narrated by Muslim, about the persons firstly to be judged on the Day of Resurrection (Oki)

b. From Nu'man narrated by Bukhari, that the Prophet did not want to be a witness if he did not do justice (Maulana)

c. Hadith narrated by Bukhari and Muslim, about the four characteristics of the hypocrites human (Maulana and NASH group)

d. Hadith narrated by Thabrani and Hakim, that when a man is married, he has completed one half of his religion (NASH group)

e. Hadith narrated by Muslim, that the worst people are those who carry two-faces (NASH group)

f. In Riyadhus Shalihin, that in a journey we should pay attention to vehicles, rest, grouping, and prayer (Maulana)

Third, by mentioning the outline of hadith or a narrative:

a. A devout person, his soul gathered with devout people based on the hadith of Prophet Muhammad (Kahfi)

b. There are men who have good both religion and morals apply and got rejected, there will be calumny (Lulu)

c. Seven types of people who will get salvation on the Day of Resurrection (Oki)

d. The Prophet's journey of Isra' Mi'raj (Maulana)

e. Handzalah asked by Abu Bakr about paradise close to the Prophet, etc. (Oki)

f. Narrative of Ibrahim bin Adham about ten things which make a prayer is not granted (Cecep)

g. The situation in mahsyar field where the human's head looked up, one-mile distance, walking, driving, their faces are dragged (Oki)

h. The situation of mahsyar field is like 50,000 years for stray people, dhuhur-ashar for devout people (Kahf)

i. The story of a woman who dreams her hands burned (Maulana)

j. Good matter but hated by God, divorce (Oki)

k. Abu Bakar vowed not to live a family due to cases of ifk calumny (Maulana) 
1. Kafarat for the violated vow, by feeding ten poor people, clothes for ten poor people, freeing slave or fasting for three days (Maulana)

m. The Prophet is entrusted with the goods of the disbelievers for three days, and remains trustworthy (Oki)

n. Three secrets of Allah: Fortune, Soul Mate, and Death (Maulana)

o. The narrative of a devout daughter who did not marry until she died, and prayed for his father to not go to heaven (Sham)

p. Abdullah bin Ubay bin Salul who built a mosque and people were ordered to burn the mosque because he was a hypocrite (Sham).

q. Hindun-Sufyan's wife, who is allowed to steal her husband's money because her husband is too stingy (Lulu)

From the above explanation, no speaker mentions the narrative of hadith with the complete sanad and matan, hadith translation, referral source of hadith book, and explains the quality of the hadith, neither orally nor visually in writing on the screen. The the speakers tend to quote the hadith by mentioning part of the matan of the hadith, mentioning some of the sanad (first or last transmitters) and outline of the hadith, or only explaining the outline of the hadith/narrative.

Quoting the sanad and matan of the hadith incompletely and not explaining the source of the Book will make it difficult to check and make it less clear to know the position of the hadith used as the referral source; whether what is delivered is the hadith of the Prophet, the opinion of the scholars, narrative, syi'ir, or the other; whether the hadith in question is really a hadith, maqbul (shahih or hasan), or mardud (dhai'f and maudhu'); whether the hadith quoted is marfu' (sourced from the Prophet), mauquf (from the Companions of the Prophet), or maqthu' (from tabi'in). Mentioning the complete form of the narrative and the source of the quotation would further emphasize the profundity and the readiness of $d a^{\prime} i$ in delivering his $d a^{\prime} w a h$ material, and what he delivers is more accountable.

As for the way of interpreting the hadith, the $d a^{\prime} i$ were more likely to interpret textually from the sound of the text, and did not refer to other Books of hadith, Book of Syarah, Asbab Wurud al-Hadis, Tarikh al-Mutun, al-Nasikh wa al-Mansukh, Mukhtalifil Hadis, Ghharib al-Hadits, etc. as the materials explaining the content of hadith, since almost all explanations concerning the quoted narratives were the explanations free of the translation of hadith texts conveyed, without mentioning the historical context of the Arab society at the Prophet's time concerning the themes discussed and the different views of the scholars in understanding the hadith and how the hadith is understood in the present context.

For example, Lulu and Kahfi in "Jurus Ampuh Cari Jodoh" (The Effective Ways to Find a Soul Mate) only briefly explained the reasons why a person is married that is because of four things, namely, because of their wealth, nasab, physical appearance, and religion. Then choose those with a good religion. See the ID card, they must have the same faith and religion. The explanation of the hadith should be deepened that why nasab, physical appearance, and wealth should not be a primary or preferred consideration in choosing a partner? Because it is material, not lasting, and will gradually disappear over time/age. While religion is perpetual. The explanation of ad-diin should also be clarified, not just the Islamic status on the ID card, or a person who studies religion, or has a lot of religious knowledge, or reads yellow book (Kitab Kuning), or studies religion for a long time, good at reciting the Qur'an, or memorizing many surah (chapters) in the Qur'an, or clever in preaching, because these things are still material. Religion is more to the personality traits that reflect one's religious, daily behavior, his personality shows the practice of Islam in worship, in having social 
interaction/mu'amalah, and interacting with nature and other creatures. Therefore, the $a d-$ diin indicator exists on its natures, such as responsibility, honesty, persistence, respect for others, and so on. This needs to be explained, given the phenomena in Indonesia, many people who understand ad-diin, limited only to their Islamic status on the ID card or religious educational background or can read al-Qur'an well. In fact, many people marry those with the same religion, or have a lot of religious knowledge, known as usthad or scholars, but the marriage is unhappy and not lasting, then they blame that "the hadith material is not universal", although actually the concept of understanding needs to be straightened out.

Similarly, when Syamsuddin Nur described a narrative about the story of a devout woman who did not marry until she died because her father objected to marry her with some men who came to propose her, because they were poor, the nasab was not equal, or had low education. At the end of her life, she prayed for her father not to go to heaven until three times and her father was asked to agree her prayer. The question is, is such kind of prayer appropriate to be given to the father who has raised and taken care of her? Or can she be called devout, if she has such a vengeful nature to her own father? The explanation of the narrative should be related to other narratives which emphasize the necessity to behave and say politely to the parents, even if the aqidah (theology) is different.

Understanding the hadith as the ideal guidance/qudwah hasanah should be able to answer the actual issues in the global era that many people often asked. Many devout Muslims are more focused on individual worship. Muslims are rarely seen communally doing solutive movements to solve the issues of the nation. On the contrary, they tend to cause problems to the nation, such as corruption, illegal logging, criminal acts, etc. Even these problems are mostly coming from the Muslims, the majority population in Indonesia. The lack of synchrony between ideality and reality on the one hand often raises the question of where is al-Islam rahmatan lil 'aalamiin (Islam as a carrier of mercy for the universe). Of how the studies of Islam of the hadith of the Prophet became the solution to various problems of life and the problems of the nation. A very textual understanding related to dhahiriyyah of the hadith needs deeper explanation by contextualizing its content in the Indonesian context.

\section{Toward the Profundity of the Material}

Without prejudice to the appreciation of the religious talk show program which got good response for more than six years, because the program is quite entertaining, has the language easy to understand, and delivered with a casual style and humor, interspersed with songs or inspirational stories, or fresh dialogue between the spectators at the studio or the guests. However, for the profundity and accuracy of the hadith materials, then in referring the narrative of hadith as the $d a^{\prime}$ wah legitimation postulate should be more improved, since the usthad/usthadah did not explain the sanad and matan of the hadith completely and the source of the Book and the quality of the hadith in question.

Indeed, a detailed and lengthy explanation would give the impression "too deep or too scientific material". So, the technical solution that can be done is by explaining the hadith text, translation, the source of the Book, and its quality visually on the screen, so as not to reduce the time duration to explain further.

Since Islam Itu Indah program has a very high rating and favored by television viewers, the importance of media literacy for viewers not to be brought on the material that is less standard must be realized. Therefore, inputs and more involving professionals in Islamic knowledge are needed to prepare the sources of material and reading sources 
for the speakers, so that the content of the talk material is not deviated from what is expected.

In detail, the author gave three recommendations: First, to complement the sources, the text of hadith, and the quality of the hadith in quoting the hadith text, and to be displayed visually on the television screen. Second, in interpreting the text of hadith to be more based on the reading of the syarah book and contextualizing with Indonesian context. Third, to involve people who have a strong background in the field of Islamic knowledge, especially the knowledge of hadith in helping to arrange the script as the talk material to be used, in addition to other fields (Al-Qur'an/interpretation, Fiqh, Sirah).

\section{Conclusion}

The profundity of the hadith materials on Islam Itu Indah religious program was still very lacking from two aspects. First, in referring the narrative of hadith as the $d a^{\prime} w a h$ legitimation postulate, it generally did not explain the sanad and matan of the hadith completely, the sources of the Book, and the quality of the hadith in question. Second, in explaining the content of hadith, it generally interpreted textually and a brief explanation of the translation of the hadith texts conveyed, without mentioning the historical context of Arab society at the Prophet's time related to the themes discussed, and the different views of the scholars in understanding the hadith and how the hadith is understood in the present context and did not refer to the Books of Hadith, Syarah, Asbab Wurud al-Hadis, Tarikh al-Mutun, al-Nasikh wa al-Mansukh, Mukhtalifil Hadis, Ghharib al-Hadits, etc. Therefore, it is necessary to involve the professionals in Islamic knowledge to prepare the material sources (for the speakers), so that the content of the talk material is still qualified, and visualization of the text of the hadith and its explanation is also needed (for the television viewers).

\section{References}

Amelia, C (2005). Literasi Media, Upaya Cerdas dalam Mengkonsumsi Tayangan Televisi. Capture, Vol (7): 1.

'Ajjaj al-Khatib, Muhammad. Usul al-Hadis 'Ulumuhu wa Mustalahuhu (1989). Beirut: Dar al-Fikr.pp. 231,232,305, 358-363.

Arifin, N. (2015). Retorika Dakwah Ustadz Maulana Dalam Acara "Islam Itu Indah" di Trans TV. Yogyakarta: UIN Sunan Kalijaga, 44-73

Dawud, M. (2015). Tayangan Dakwah dan Lahirnya Da`i Selebriti, Al Adalah.Vol (18): 2

Habib, Z. (2014). Analisis Isi Program Islam Itu Indah di Stasiun Trans TV, Jakarta: Universitas Muhammadiyah Jakarta. pp.6-15.

Hawa, A. (2016). Retorika Dakwah Oki Setianan Dewi Dalam Acara "Islam Itu Indah" di Trans TVedisi 18 april 2016. Yogyakarta: UIN Sunan Kalijaga. pp.50-81.

Ismail, S. (1992). Metodologi Penelitian Hadis Nabi. Jakarta: Bulan Bintang.

----., (1994). Hadis Nabi yang Tekstual dan Kontekstual Telaah Ma'ani al-hadis tentang Ajaran Islam yang Universal Temporal dan Lokal. Jakarta: Bulan Bintang. pp.1121.

(1995). Kaedah Kesahihan Sanad Hadis Telaah Kritis dan Tinjauan dengan Pendekatan Ilmu Sejarah.Jakarta: Bulan Bintang.

Maulana, I. (2015). Ustadz Muhammad Nur Maulana pada Program "Islam Itu Indah" di Trans TV. Semarang: UIN Walisongo. pp.61-74.

Najwah, N (2016). Living Hadis sebagai New Trend Dalam Studi hadis. Makalah.

Pratiwi, M. (2014). Interpretasi Khalayak terhadap Program Acara "Islam Itu Indah" di Trans TV. Jurnal Interaksi. Vol (III) 1 
Umminur, J. (2015). Tanggapan Mahasiswa Fakultas Dakwah dan Komunikasi UIN Walisongo Terhadap Dakwahtainment di Televisi (Program Siaran "Islam Itu Indah" di Trans TV. Skripsi. UIN Walisongo: Semarang.pp.58-69.

Setyaningsih, R. (2012). Persepsi Umat Beragama Terhadap Siaran Keagamaan di Trans TV. Yogyakarta: Universitas Muhammadiyah Yogyakarta. pp.61-67.

Samsudin, S. (2007). Metodologi Penelitian Living al-Qur'an dan Hadis, Yogyakarta: Teras.

al-Qaradawi, Y. (1990). Kaifa Nata 'amal ma'a al-Sunnah al-Nabawiyyah: Ma alim wa Dawabit. USA: al-Ma'had al-'Alami li al-Fikr al-Islami.

https;// celebrity.okezone.com, accessed 2017, February 22.

Htttp://islamituindah.com, accessed 20, March 20.

CD Mausu 'ah al-Hadis al-Syarif al-Kutub al-Tis 'ah

https://www.youtube.com/watch?v=K7gzxJZHOi8 / Islam itu indah, LIBURAN YUUK, 2017, January 07.

https://www.youtube.com/watch?v=S9GazMT8SGI / Islam itu indah, HIDUP SETELAH MATI, 2017, February 15.

https://www.youtube.com/watch?v=4MLt9erIbuY JJANGAN PILIH KASIH， 2017, February 16.

https://www.youtube.com/watch?v=fQyatbTblfk / Islam itu indah, MANA JANJIMU, 2017, February 17.

https://www.youtube.com/watch?v=PcWq0SE lbo / Islam itu indah, JURUS AMPUH CARI JODOH, 2017 , March 16.

https://www.youtube.com/watch?v=fD--IzP1boM / Islam itu indah, SANG PENJILAT, 2017, March 18. 